\title{
Spawning cycle of onychoteuthid squids in the southern Indian Ocean: new information from seabird predators
}

\author{
Yves Cherel*, Henri Weimerskirch \\ Centre d'Etudes Biologiques de Chizé, UPR 1934 du Centre National de la Recherche Scientifique, \\ 79360 Villiers-en-Bois, France
}

\begin{abstract}
Cephalopods play an important role in the trophic web of the Southern Ocean, but little information is available on their biology. The 2 largest sub-Antarctic seabirds, the king penguin Aptenodytes patagonicus and the wandering albatross Diomedea exulans, feed primarily on squids during the austral winter at the Crozet Islands. We examined a large number of accumulated cephalopod beaks in the stomach of these birds together with some undigested items; first, to understand how these 2 predators share the squid resource during winter, a period of supposed low food availability, and, second, to use a diving and a flying seabird as biological samplers of Southern Ocean cephalopods. Individuals of the family Onychoteuthidae formed the bulk of the squid diet, accounting for 72.6 and $57.0 \%$ of the number of lower beaks in samples from king penguins and wandering albatrosses, respectively. Seven different species were identified, the 3 main squids being Kondakovia longimana $(38.8$ and $28.0 \%$ by number for penguins and albatrosses, respectively), Moroteuthis ingens (13.5 and $26.2 \%$ ) and $M$. knipovitchi (20.1 and 2.3\%). Both seabirds preyed upon the same cephalopod species, but penguins primarily took small- to medium-sized juveniles $(99.0 \%$ of the onychoteuthids) and albatrosses preyed on larger adult specimens $(96.0 \%)$. Fresh remains indicated that adult $K$. longimana and $M$. ingens were mature individuals which, as shown by satellite tracking of albatrosses, were taken over the slope and nearby oceanic waters surrounding the archipelago. The present study indicates that mating/spawning of $K$. longimana and $M$. ingens occurs in Crozet waters during the winter months. It also extends the biogeography of K. longimana to north of the Antarctic Polar Front, in the Polar Frontal Zone, where it has not previously been recorded.
\end{abstract}

KEY WORDS: Kondakovia longimana Moroteuthis ingens - Moroteuthis knipovitchi - Wandering albatross King penguin - Trophic web - Antarctica

\section{INTRODUCTION}

In the Southern Ocean, squids constitute a key group in the pelagic food web, but little information is available on species composition, distribution and biology (Kock 1987). Several factors are primarily responsible: (1) the small number of oceanographic cruises devoted to the collection of cephalopods, cruises being restricted in time and space; (2) the difficulty of scientifically sampling active squids that are able to avoid being

•E-mail: cherel@cebc.cnrs.fr captured by conventional techniques; and (3) in most species, specimens caught are larvae and juveniles, adults rarely being sampled or even unknown. Comparison of net-caught cephalopods with those eaten by predators indicates that birds and mammals catch larger specimens and a greater diversity of species than sampling gear (Rodhouse 1990), which emphasizes the usefulness of predators for obtaining valuable information on cephalopod biology. Indeed, recent studies using dietary data and satellite tracking of seabirds have localized previously unknown concentrations of pelagic squids (Cherel \& Weimerskirch 1995 , Rodhouse et al. 1996). 
In the Southern Ocean, phytoplankton production is mostly limited to the summer months, which, in turn, leads to an enhanced concentration of zooplankton and nekton biomasses in surface layers (Smith \& Schnack-Schiel 1990). These animals provide an abundant food source for seabirds and marine mammals at a time when most of them are engaged in breeding activities. Conversely, winter is a season of food scarcity due to the seasonal migration of marine organisms into deeper layers of the water column, so only a few top predators reproduce at this time (Croxall 1984). For the 2 largest sub-Antarctic seabirds, the king penguin Aptenodytes patagonicus and the wandering albatross Diomedea exulans, the long growth period of chicks is related to bird size, which means that the austral summer/autumn growth phase is too short to allow the birds to fledge. These 2 species have to cope with low marine resource availability in winter in 2 opposite ways. Due to a low adult feeding rate, king penguin chicks are underfed at this time (Cherel et al. 1987), and most of their energy expenditure is covered by the use of endogenous energy reserves built up during the previous autumn (Cherel et al. 1993a). Chicks of wandering albatrosses, however, continue growing during the austral winter, being fed by their parents at short intervals for the whole period (Tickell 1968, Lequette \& Weimerskirch 1990).

Both king penguins and wandering albatrosses feed their chicks with fish and squid. King penguins are myctophid fish eaters that shift to a squid diet during the winter months (Adams \& Klages 1987, Cherel et al. 1993b, Moore et al. 1998), while wandering albatrosses are mainly squid eaters that complement their diet with neritic fishes and carrion (see review in Cherel \& Klages 1998). At the Crozet Islands (southern Indian Ocean), the winter diet of the 2 species is dominated by squids of the same family, the Onychoteuthidae (Ridoux 1994, Cherel et al. 1996, Weimerskirch et al. 1997).

The aim of the present study is to compare the cephalopod diet of king penguins and wandering albatrosses at the Crozet Islands to investigate, first, the feeding ecology of diving and flying seabirds during a period of supposed low prey availability, the austral winter, and, second, the biology of a major component of the marine ecosystem, the onychoteuthid squids, through the use of predators as biological samplers. The study focuses on the analysis of accumulated items, because the high number of accumulated beaks allows large numbers to be assessed rather than concentrating on the smaller number of fresh specimens found in the bird's stomach. Species identification of cephalopods from the external features of lower beaks is now possible due to the availability of a reliable comparative key in the literature (Clarke 1986) and reference collections.

\section{MATERIALS AND METHODS}

Fieldwork was carried out on Île de la Possession, Crozet Archipelago, located in the southern Indian Ocean $\left(46^{\circ} \mathrm{S}, 52^{\circ} \mathrm{E}\right.$ ). King penguin samples were collected during 3 successive winters (1990, 1991 and 1992) in the breeding colony at La Baie du Marin. Between 15 and 17 adult penguins were stomachflushed (Gales 1987) each year during late June-early July, thus totalling 47 samples over the 3 yr. Adult king penguins were randomly chosen from birds on arrival at the colony after a foraging trip, but before they fed their chick. Wandering albatross samples were collected during the austral winter in 1992 ( $\mathrm{n}=$ 24) and 1994 ( $n=10$ ) by induced regurgitation of chicks after a returning parent had completed feeding. For comparison, data previously collected in 1982 ( $n=37$ food samples) (Ridoux 1994) have been included in the 'Results'.

All the stomach contents were returned deep-frozen $\left(-20^{\circ} \mathrm{C}\right)$ to the laboratory in France for analysis. Each sample was thawed and drained, and accumulated squid beaks were subsequently sorted and kept in $70 \%$ ethanol. Fresh remains were divided into broad prey classes (fish, squid, others) which were weighed to calculate their proportion by mass in the diet. Lower beaks of cephalopods were identified by reference to features given by Clarke (1986) and Imber (1992) and by comparison with material held in our own reference collection. Lower rostral length (LRL) of squid beaks was measured to $0.1 \mathrm{~mm}$ with vernier calipers. Lower beaks with undarkened or darkening wings were considered as belonging to juvenile squids, and beaks with fully keratinized wings to adults (Clarke 1986). Allometric equations given by Clarke (1986), Adams \& Klages (1987), and Jackson (1995) were used to estimate mantle length (ML) and whole wet mass (M) from LRL. Because Moroteuthis ingens shows sex-specific relationships between LRL, ML and M (Jackson 1995), the values of $\mathrm{ML}$ and $\mathrm{M}$ given in the text are the means of those calculated for males and females.

Cephalopod beaks can persist in predator stomachs for weeks and even months, thus overemphasizing their importance in seabird diets (Furness et al. 1984). Consequently, they were not taken into account in the present study when calculating the proportion by mass in the diet of the broad prey classes. Dietary samples of king penguins were collected from adult birds during the chick-rearing period; this precludes the accumulation of squid beaks over a long time in adult stomachs because beaks are passed to the chick during feeding. Conversely, food samples of wandering albatrosses were collected from chicks which had accumulated beaks from hatching time, in mid-March, to the middle of winter. Additional samples collected in the first 2 mo 
Table 1. Interannual comparison of the number of lower beaks of the main onychoteuthid prey in the diet of king penguins and wandering albatrosses in winter

\begin{tabular}{|c|c|c|c|c|c|c|}
\hline \multirow[t]{2}{*}{ Species } & \multicolumn{3}{|c|}{ King penguins } & \multicolumn{3}{|c|}{ Wandering albatrosses } \\
\hline & $\begin{array}{c}1990 \\
(n=15)\end{array}$ & $\begin{array}{c}1991 \\
(n=17)\end{array}$ & $\begin{array}{c}1992 \\
(n=15)\end{array}$ & $\begin{array}{c}1982^{a} \\
(n=37)\end{array}$ & $\begin{array}{c}1992 \\
(n=24)\end{array}$ & $\begin{array}{c}1994 \\
(n=10)\end{array}$ \\
\hline Kondakovia longimana & $203(26.7 \%)$ & $142(43.0 \%)$ & $637(44.2 \%)$ & $650(52.5 \%)$ & $132(10.3 \%)$ & $477(52.8 \%)$ \\
\hline Moroteuthis ingens & $226(29.7 \%)$ & $20(6.1 \%)$ & $95(6.6 \%)$ & $60(4.8 \%)$ & $523(40.9 \%)$ & $48(5.3 \%)$ \\
\hline Moroteuthis knipovitchj & $138(18.2 \%)$ & $103(31.2 \%)$ & $267(18.5 \%)$ & $43(3.5 \%)$ & $30(2.3 \%)$ & $20(2.2 \%)$ \\
\hline $\begin{array}{l}\text { Total number of } \\
\text { accumulated beaks }\end{array}$ & $760(100 \%)$ & $330(100 \%)$ & $1440(100 \%)$ & $1238(100 \%)$ & $1278(100 \%)$ & $903(100 \%)$ \\
\hline
\end{tabular}

of the chick-rearing period, however, contained only a few accumulated items ( $\mathrm{n}=83$ lower beaks from 30 pooled samples), including only 21 lower beaks from onychoteuthid squids (unpubl. data). Thus, the large number of accumulated beaks collected from penguin and albatross stomachs in the present study is likely to give information on cephalopod prey ingested during the winter months.

Data were statistically analysed using SYSTAT 7.0 for Windows. Values are means $\pm \mathrm{SD}$.

\section{RESULTS}

\section{Squid prey of king penguins}

Analysis of fresh remains over the $3 \mathrm{yr}$ of the study period indicated that fishes and squids accounted for 66.1 and $33.9 \%$ of the food by mass, respectively, during the winter months. The squid part of the king penguin diet was dominated by onychoteuthid squids ( $70.5 \%$ of the squid prey and $95.8 \%$ of squid reconstituted mass), the main item being Moroteuthis ingens

Table 2. Numbers and percentages of juveniles (lower beaks with undarkened and darkening wings) and adults (beaks with darkened wings) of onychoteuthid squids eaten by king penguins and wandering albatrosses in winter

\begin{tabular}{|lcccc|}
\hline \multirow{2}{*}{ Species } & \multicolumn{2}{c}{ King penguins } & \multicolumn{2}{c|}{ Wandering albatrosses } \\
& Juveniles & Adults & Juveniles & Adults \\
\hline Kondakovia longimana & $982(100.0 \%)$ & $0(0.0 \%)$ & $22(3.6 \%)$ & $587(96.4 \%)$ \\
Moroteuthis ingens & $334(97.9 \%)$ & $7(2.1 \%)$ & $28(4.9 \%)$ & $543(95.1 \%)$ \\
Moroteuthis knipovitchi & $497(97.8 \%)$ & $11(2.2 \%)$ & $0(0.0 \%)$ & $50(100.0 \%)$ \\
Moroteuthis robsoni & - & - & $0(0.0 \%)$ & $7(100.0 \%)$ \\
Moroteuthis sp. B & $7(100.0 \%)$ & $0(0.0 \%)$ & - & - \\
Onychoteuthis banksi & - & - & $0(0.0 \%)$ & $3(100.0 \%)$ \\
Onychoteuthis sp. C ${ }^{\mathrm{a}}$ & - & - & $0(0.0 \%)$ & $3(100.0 \%)$ \\
& $1820(99.0 \%)$ & $18(1.0 \%)$ & $50(4.0 \%)$ & $1193(96.0 \%)$ \\
Total & & & & \\
aFollowing Imber (1992) & & & & \\
\hline
\end{tabular}

$126.5 \%$ of the squid prey, but, owing to its large size, $88.0 \%$ of the squid reconstituted mass).

A total of 2530 identifiable accumulated lower beaks was recovered from the 47 stomach contents. Onychoteuthids formed the bulk of the squid diet determined from accumulated items, accounting together for $72.6 \%$ of the total number of cephalopod prey. Four species of onychoteuthids were identified, including the 3 most important squid prey and 1 rare item; they were Kondakovia longimana (38.8\% by number), Moroteuthis knipovitchi (20.1\%), M. ingens (13.5\%), and Moroteuthis sp. B $(0.3 \%)$. Thirteen other taxa were found, including 6 common species (Gonatus antarcticus: $7.9 \%$; Chiroteuthis sp.: 6.1\%; Alluroteuthis antarcticus: $5.5 \%, 2$ to 3 species of the genus Brachioteuthis grouped together: $4.7 \%$; and Histioteuthis atlantica: $1.4 \%$ ), and 7 occasional or rare prey items.

Cephalopod beaks were 2 and 4 times more numerous in winter 1992 than in winters 1990 and 1991, re. spectively (Table 1). The relative numbers of the 3 main species of onychoteuthids varied significantly between years (Pearson chi-squared test; Kondakovia longimana: $\chi_{2}^{2}=67.18, p<0.0001 ; M O-$ roteuthis ingens: $\chi^{2}{ }_{2}=246.31, \mathrm{p}<$ $0.0001 ; M$. knipovitchi: $\chi_{2}^{2}=$ 29.36, $p<0.0001$ ). K. longimana dominated the squid diet in 1991 and 1992 ( 43.0 to $44.2 \%$ ), but not in 1990 when it co-occurred with $M$. ingens as the main items (26.7 and $29.7 \%$, respectively).

All individuals of Kondakovia longimana eaten by king penguins were juveniles, as indicated by the undarkened wings of lower beaks (Table 2). Penguins fed on specimens showing a wide range in size, with the average LRL being $2.2 \pm 1.7 \mathrm{~mm}$ (ML: $61 \pm$ 

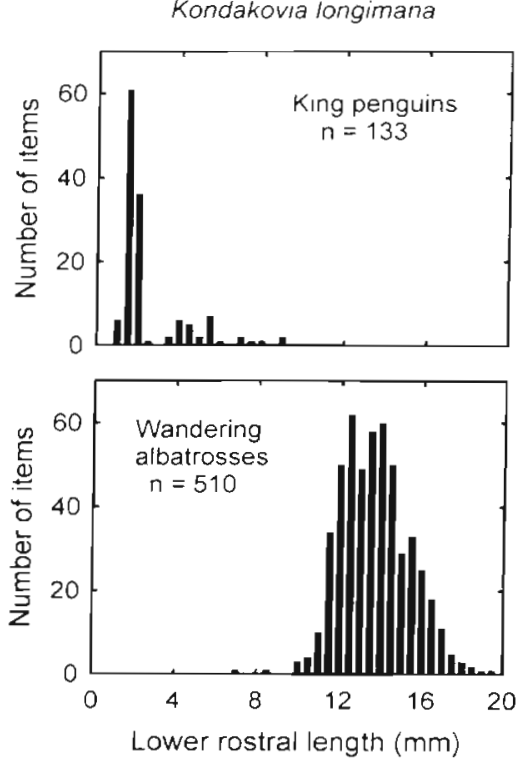

Fig. 1. Number of accumulated lower beaks of Kondakovia longimana in the stomach contents of king penguins $(n=47$. totalling 982 lower beaks of $K$. longimana, including 133 measurable items) and wandering albatrosses ( $n=34,609$ lower beaks, 510 measurable items) at the Crozet Islands during winter as a function of lower rostral length

$64 \mathrm{~mm} ; \mathrm{M}: 37 \pm 103 \mathrm{~g})$; the smallest and largest specimens had a LRL of $0.8 \mathrm{~mm}$ (ML: $6.9 \mathrm{~mm}$; $\mathrm{M}: 0.3 \mathrm{~g}$ ) and $8.7 \mathrm{~mm}$ (ML: $302 \mathrm{~mm} ; \mathrm{M}: 648 \mathrm{~g}$ ), respectively. There was a mode at 1.0 to $1.5 \mathrm{~mm}$ LRL (ML: $25 \mathrm{~mm}$; M: $1.7 \mathrm{~g}$ ) (Fig. 1), which was not, however, representative of the main class size eaten. A major bias arose from the eroded state of the lower beaks which, due to the loss of undarkened wings, precluded any measurements on the majority of beaks ( $86 \%$ ) from juvenile squids.

A larger proportion of lower beaks (55\%) of Moroteuthis ingens was measured (Fig. 2). The mean LRL was $5.7 \pm 0.6 \mathrm{~mm}$ (ML: $233 \pm 21 \mathrm{~mm} ; \mathrm{M}: 408 \pm 134 \mathrm{~g}$ ), including a mode at 5.5 to $5.8 \mathrm{~mm}$ (ML: $230 \mathrm{~mm} ; \mathrm{M}: 380 \mathrm{~g}$ ) and a few individuals at 8.0 to $8.3 \mathrm{~mm}$ (ML: $316 \mathrm{~mm}$; $\mathrm{M}: 1001 \mathrm{~g}$ ). The mode corresponded to juveniles, which constituted $97.9 \%$ of squids eaten by king penguins, the remainder being adult specimens (Table 2). LRL of juveniles differed significantly between years (Table 3; ANOVA, $F_{2,178}=40.57$, $\mathrm{p}<0.001$ ): squids eaten by penguins were much smaller in 1991 than in 1990 (post hoc Tukey HSD multiple comparison test: $p<0.001)$ and $1992(p<0.001)$, the difference also being significant between 1990 and 1992 ( $p=0.033$ ).

The mean LRL of beaks of Moroteuthis knipovitchi was $2.8 \pm 0.9 \mathrm{~mm}$ (ML: $108 \pm 34 \mathrm{~mm} ; \mathrm{M}: 52 \pm 94 \mathrm{~g}$ ), including a large majority of juvenile

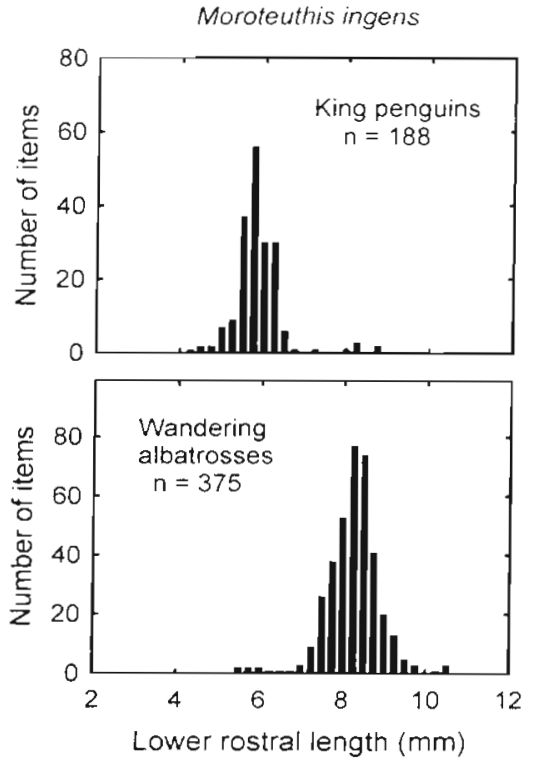

Fig. 2. Number of accumulated lower beaks of Moroteuthis ingens in the stomach contents of king penguins ( $\mathrm{n}=47$, totalling 341 lower beaks of $M$. ingens, including 188 measurable items) and wandering albatrosses ( $\mathrm{n}=34,571$ lower beaks, 375 measurable items) at the Crozet Islands during winter as a function of lower rostral length

squids (97.8\%) and a few adult specimens (Table 2). Three size classes occurred; 2 main modes of juveniles at 2.0 to $2.3 \mathrm{~mm}$ (ML: $83 \mathrm{~mm}_{i} \mathrm{M}: 14 \mathrm{~g}$ ) and at 3.0 to $3.3 \mathrm{~mm}$ (ML: $122 \mathrm{~mm} ; \mathrm{M}: 51 \mathrm{~g}$ ), and a discrete mode of adults at 5.5 to $5.8 \mathrm{~mm}$ (ML: $219 \mathrm{~mm}$; M: $396 \mathrm{~g}$ ). Finally, 7 beaks of Moroteuthis sp. B were identified in 1 sample. They were eroded, thus precluding any measurements. However, the size of the lower beaks indicated that they belonged to small juvenile squids.

\section{Squid prey of wandering albatrosses}

Analysis of fresh remains over the $3 \mathrm{yr}$ indicated that squid, fish and carrion accounted for $74.8,17.6$ and $7.6 \%$

Table 3. Lower rostral lengths of accumulated beaks of the squid Moroteuthis ingens eaten by king penguins and wandering albatrosses at Crozet Islands during the winter months. Values are means $\pm \mathrm{SD}$, with number of items in parentheses

\begin{tabular}{|lcccccc|}
\hline & \multicolumn{3}{c}{ King penguins } & \multicolumn{2}{c|}{ Wandering albatrosses } \\
& 1990 & 1991 & 1992 & 1992 & 1994 \\
\hline Small-size mode & $5.6 \pm 0.3$ & $4.7 \pm 0.4$ & $5.8 \pm 0.3$ & $6.1 \pm 0.6$ & - \\
& $(128)$ & $(9)$ & $(44)$ & $(12)$ & \\
Large-size mode & $7.9 \pm 0.6$ & - & $8.2 \pm 0.3$ & $8.2 \pm 0.5$ & $8.8 \pm 0.6$ \\
& $(3)$ & & $(4)$ & $(352)$ & $(11)$ \\
Total & $5.7 \pm 0.5$ & $4.7 \pm 0.4$ & $6.0 \pm 0.7$ & $8.1 \pm 0.6$ & $8.8 \pm 0.6$ \\
& $(131)$ & $(9)$ & $(48)$ & $(364)$ & $(11)$ \\
\hline
\end{tabular}


of the food by mass, respectively, during the winter months. The squid part of the wandering albatross diet was dominated by onychoteuthid squids $160.4 \%$ of the total number of fresh squids, and $89.2 \%$ of the identifiable specimens, Table 4). By far the main items were Kondakovia longimana in 1982 and 1994, and Moroteuthis ingens in 1992 (Table 4).

A total of 2181 accumulated lower beaks was identified from the 34 chick regurgitations collected in 1992 and 1994. Onychoteuthid squids contributed $57.0 \%$ by number to the cephalopod diet of wandering albatrosses in winter. Six species of that family were found, including the 2 most numerous prey (Kondakovia longimana: $28.0 \%$, and Moroteuthis ingens: $26.2 \%$ ), 1 regular item (M. knipovitchi: $2.3 \%$ ) and 3 rare squids ( $M$. robsoni: $0.3 \%$; Onychoteuthis banksi: $0.1 \%$; and Onychoteuthis sp. C: $0.1 \%$ ). Other common cephalopod taxa were Histioteuthis eltaninae $(9.8 \%)$, different species of the genus Histioteuthis grouped together (10.0\%) and Galiteuthis glacialis $(9.6 \%)$. Twenty-five other species were found, including 3 regular prey (Martialia hyadesi: $4.4 \%$; Alluroteuthis antarcticus: $1.9 \%$; and Cycloteuthis akimushkini: $1.9 \%$ ) and 22 occasional or rare items.

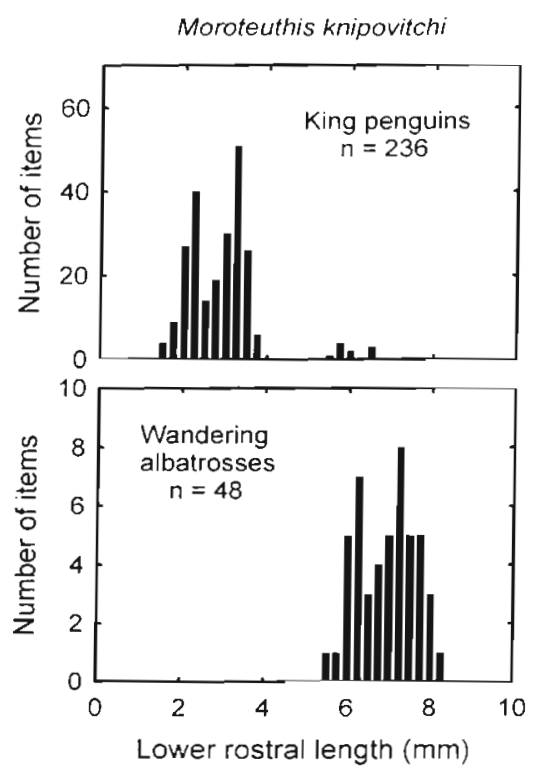

Fig. 3. Number of accumulated lower beaks of Moroteuthis knipovitchi in the stomach contents of king penguins $(n=47$, totalling 508 lower beaks of $M$. knipovitchi, including 236 measurable items) and wandering albatrosses ( $\mathrm{n}=34,50$ lower beaks, 48 measurable items) at the Crozet Islands during winter as a function of lower rostral length. Note different scales of ordinates
The relative numbers of Kondakovia longimana and Moroteuthis ingens, but not of $M$. knipovitchi, varied significantly between years (Pearson chi-squared test ${ }_{i}$ $K$. longimana: $\chi^{2}=615.85, \mathrm{p}<0.0001 ; M$. ingens: $\chi^{2}=$ 684.62, $\mathrm{p}<0.0001 ;$ M. knipovitchi: $\chi^{2}=4.20, \mathrm{p}=0.123$ ). $M$. ingens dominated the diet in 1992 but not in 1982 and 1994 ( 40.9 vs 4.8 to $5.3 \%$ ), and the reverse was true for $K$. longimana $(10.3$ and 52.5 to $52.8 \%$, respectively) (Table 1).

Most individuals of Kondakovia longimana eaten by albatrosses were adults $(96.4 \%$ ) (Table 2 ). The average measured LRL was $13.5 \pm 1.7 \mathrm{~mm}$ (ML: $480 \pm 63 \mathrm{~mm}_{i}$ $\mathrm{M}: 2722 \pm 1106 \mathrm{~g}$ ), with a mode at 12.0 to $12.5 \mathrm{~mm}$ (ML: $435 \mathrm{~mm}$; M: $1921 \mathrm{~g}$ ) (Fig. 1). As with the penguin prey, the size of juveniles was difficult to assess because the loss of wings precluded LRL measurement; the LRL of 5 large juveniles was $8.8 \pm 1.3 \mathrm{~mm}$ (ML: $307 \pm 47 \mathrm{~mm}$; M: $717 \pm 273 \mathrm{~g}$ ). No interannual difference was observed in the size of $K$. longimana eaten by wandering albatrosses in winter $(13.6 \pm 1.6 \mathrm{~mm}, \mathrm{n}=127$, and $13.4 \pm 1.7 \mathrm{~mm}, \mathrm{n}=383$, for 1992 and 1994, respectively; 2 -sample $t$-test, $t=1.18, \mathrm{p}=0.239$ ).

The mean LRL of Moroteuthis ingens was $8.1 \pm$ $0.7 \mathrm{~mm}$ (ML: $316 \pm 23 \mathrm{~mm} ; \mathrm{M}: 1021 \pm 218 \mathrm{~g}$ ), with a mode at 8.0 to $8.3 \mathrm{~mm}$ (ML: $316 \mathrm{~mm} ; \mathrm{M}: 1001 \mathrm{~g}$ ) and a few individuals at 5.5 to $5.8 \mathrm{~mm}$ (ML: $230 \mathrm{~mm}$; M: 380 g) (Fig. 2). The mode corresponded to adults that formed $95.1 \%$ of the squids eaten (Table 2), the remainder being juvenile specimens. Adult squids eaten by albatrosses in 1992 were significantly smaller than those eaten in 1994 (Table 3, Mann-Whitney $U$ test, $U=824, \mathrm{p}=0.001$ ).

All the specimens of Moroteuthis knipovitchi eaten by wandering albatrosses were adult squids (Table 2), which had a mean LRL of $6.8 \pm 0.7 \mathrm{~mm}$ (ML: $265 \pm$ $26 \mathrm{~mm} ; \mathrm{M}: 804 \pm 269 \mathrm{~g})$. Two modes were observed (Fig. 3), one at 6.0 to $6.3 \mathrm{~mm}$ (ML: $238 \mathrm{~mm}$; M: $532 \mathrm{~g}$ ) and the second at 7.0 to $7.3 \mathrm{~mm}$ (ML: $277 \mathrm{~mm}_{\text {; }} \mathrm{M}$ : $904 \mathrm{gj}$. No interannual variation was noted in the size of M. knipovitchi $(6.9 \pm 0.6 \mathrm{~mm}, \mathrm{n}=28$, and $6.7 \pm 0.8 \mathrm{~mm}$, 
$\mathrm{n}=20$, for 1992 and 1994, respectively; 2 -sample $t$-test, $t=1.15, \mathrm{p}=0.255$ ).

The few specimens of the remaining 3 species of Onychoteuthidae were all adult squids (Table 2). The average LRL for Moroteuthis robsoni, Onychoteuthis banksi and Onychoteuthis sp. C was $8.5 \pm 1.4 \mathrm{~mm}$ (ML: $330 \pm 54 \mathrm{~mm} ; \mathrm{M}: 1813 \pm 831 \mathrm{~g}$ ), $3.3 \pm 0.1 \mathrm{~mm}$ (ML: 174 $\pm 7 \mathrm{~mm} ; \mathrm{M}: 152 \pm 19 \mathrm{~g}$ ), and $4.9 \pm 0.2 \mathrm{~mm}$ (ML: $268 \pm$ $13 \mathrm{~mm} ; \mathrm{M}: 626 \pm 104 \mathrm{~g}$ ), respectively.

\section{DISCUSSION}

\section{General comments}

The present study shows that squid is the main prey of wandering albatrosses and, together with fish, is a major dietary component of king penguins at the Crozet Islands during the austral winter. Comparison between localities is difficult because studies performed at sites other than the Crozet Islands have generally been conducted over a single season, thus precluding the assessment of interannual differences. For king penguins, our data are, however, in agreement with the diet described for winter at other localities from the southern Indian Ocean (Adams \& Klages 1987, Moore et al. 1998), but not at Macquarie Island (southern Pacific Ocean), where myctophid fish forms the bulk of the food all year long (Hindell 1988). The main squid prey (by number) consumed by king penguins in winter varies according to the areas and/or the year of sampling; they were the ommastrephid Martialia hyadesi and the 2 onychoteuthids Kondakovia longimana and Moroteuthis ingens at Heard Island in 1992 (Moore et al. 1998), and onychoteuthid squids including $K$. longimana and unidentified items at Marion Island in 1984 (Adams \& Klages 1987). At the Crozet Islands, detailed analysis of both fresh and accumulated cephalopod remains over 3 consecutive years allows us to verify that onychoteuthids dominate the squid diet of king penguins from year to year during winter; it also indicates that 3 different species are involved, namely $K$. longimana, $M$. ingens and $M$. knipovitchi (Cherel et al. 1996, the present study).

Wandering albatrosses are squid eaters (see review in Imber 1992, Cherel \& Klages 1998). In localities south of the Sub-Antarctic Front, they mainly feed in winter on Kondakovia longimana, the histioteuthid Histioteuthis eltaninae, the cranchiid Galiteuthis glacialis, and other main prey including the ommastrephid Illex argentinus at South Georgia (Rodhouse et al. 1987), Moroteuthis knipovitchi at Marion Island (Cooper et al, 1992), and $M$. ingens at Crozet Islands (the present study). $M$. ingens is generally a minor to rare item in the diet of wandering albatrosses and has not previously been reported as an important prey for that species (Cooper et al. 1992, Imber 1992, Ridoux 1994). At the Crozet Islands, $M$. ingens was, however, the main food item in 1992, but not in 1982 and 1994, during which $K$. longimana formed the bulk of the food. Together with dietary samples collected over several years at the closely related Marion Island (Cooper et al. 1992, Imber 1992), these findings show that $K$. longimana usually predominates in the winter diet of wandering albatrosses from the southern Indian Ocean; they also indicate that albatrosses are able to shift to other food sources in response to environmental changes. The fairly large number of $M$. ingens in the bird's diet in 1992 may eventually result in a year of unusually high abundance of that species in Crozet waters, as recently described for the Patagonian shelf in 1994 (Jackson et al. 1998a).

\section{Comparison between king penguins and wandering albatrosses}

A major finding of the present study is that king penguins and wandering albatrosses prey upon the same species of onychoteuthid squids in winter, but not the same size classes. The diving king penguin eats juveniles of Kondakovia longimana, Moroteuthis ingens and $M$. knipovitchi, while the flying wandering albatross feeds on adult specimens of $K$. longimana and $M$. ingens, the overlap in the size of prey caught by the 2 birds being quite limited (Figs. 1 to 3 ). Since penguins are known to feed on small live prey and to swallow them whole, the most likely explanation for the lack of adult squids in the diet of king penguins is their excessive size. The largest cephalopod (an adult $M$. ingens) caught by a penguin in the present study had an estimated ML and a M of $331 \mathrm{~mm}$ and $1153 \mathrm{~g}$, respectively, which is much higher than the size of myctophid fish (20 to $125 \mathrm{~mm}$ and 0.1 to $23.1 \mathrm{~g}$ ) (Cherel et al. 1996), but smaller than the average size (480 $\mathrm{mm}$ and $2722 \mathrm{~g}$ ) of adult $K$. longimana eaten by albatrosses. King penguins, thus, have the ability to occasionally catch adults of the genus Moroteuthis, but not larger specimens of $K$. longimana (Table 2).

Unlike penguins, wandering albatrosses probably depend significantly on scavenged squid (Weimerskirch et al. 1986, Cooper et al. 1992, Croxall \& Prince 1994, Cherel \& Klages 1998), large specimens being bitten into pieces by one to several birds before being ingested. This way of feeding probably explains the relatively high number of unidentified cephalopods in the fresh fraction due to the lack of buccal masses in samples (Table 4). Large to very large squid bits were, however, quite similar to those from identified squids, suggesting that most of the unidentified specimens 
were also onychoteuthids. Albatrosses rarely feed on juveniles of Moroteuthis spp. and Kondakovia longimana, probably because some of them are too small, too fast and/or occur too deep in the water column. Indeed, wandering albatrosses are surface feeders and do not dive (Prince et al. 1994), while king penguins prey on mesopelagic organisms in the 0 to $300 \mathrm{~m}$ depth range (Kooyman et al. 1992, Pütz et al. 1998). Moreover, the smallest squid eaten by wandering albatrosses have a ML $>40 \mathrm{~mm}$ (Rodhouse et al. 1987 . Cooper et al. 1992), thus excluding many small to very small individuals caught by king penguins (Adams \& Klages 1987, Cherel et al. 1996, present study).

The reason why king penguin chicks fast during winter while chicks of wandering albatrosses are regularly fed is probably related to the availability of marine resources at this time. Also, at the Crozet Islands, king penguins outnumber wandering albatrosses by 3 orders of magnitude, i.e. about 1000000 and 1700 annual breeding pairs, respectively (Weimerskirch \& Jouventin 1987, Guinet et al. 1995), resulting in a major impact of king penguins on marine resources (Guinet et al. 1996). Both the known distribution of the main prey of king penguins in winter, Moroteuthis ingens (Nesis 1987), and the hardly digested state of some specimens (Cherel et al. 1996) indicate that juveniles were caught in neritic/slope waters surrounding the archipelago. The restricted distribution of $M$. ingens to the medium-sized Crozet shelf suggests that the population of this squid is too small to sustain the fairly high number of king penguins in winter. Indeed, adult king penguins forage for themselves very far from the island at this time of year (Jouventin et al. 1994), and probably hunt to feed their chicks on their way back, as previously described during the summer months (Bost et al. 1997, Pütz et al. 1998), or, alternatively, during trips of more restricted range, as do wandering albatrosses (Weimerskirch et al. 1994, 1997). This strategy favors foraging in distant areas where penguin density is low, and avoids high intraspecific competition around the islands. Because penguins travel slowly in comparison to flying birds, the main consequence of this strategy is, however, a low chick feeding rate in winter, chick energy expenditure being covered by the use of endogenous energy reserves built up during the more favorable conditions prevailing in summer (Cherel et al. 1993a).

Within the Crozet Island avian community, wandering albatrosses are the most dependent on onychoteuthids (Ridoux 1994), and, together with giant petrels Macronectes spp., the only species of large flying seabird present in winter. Furthermore, satellite tracking indicates that only a part of the breeding population is present at a given time in the vicinity of the archipelago, adults alternating long oceanic trips to feed for themselves and shorter trips over slope waters to feed their chicks (Weimerskirch et al. 1997). Thus, the combination of their small population, their alternating foraging strategy, and high degree of food specialization allows wandering albatrosses to feed their chicks at a high rate. For this species, winter is not a period of lower prey availability in Crozet waters, which contrasts with most of the other top predators, including the king penguin.

\section{Seabirds as biological samplers of squids}

The frequent occurrence of fresh squid remains in dietary samples of king penguins and wandering albatrosses together with satellite tracking of wandering albatrosses (Weimerskirch et al. 1997) indicates that Kondakovia longimana, Moroteuthis ingens and $M$. knipovitchi are abundant organisms in waters surrounding the Crozet Islands. This is in agreement with the known biogeography of $M$. ingens and $M$. knipovitchi (Nesis 1987), but not with that of $K$. longimana, a species previously known to only occur in and south of the Antarctic Polar Front (Lubimova 1985, Kubodera et al. 1998, Xavier et al. 1999), which is located several hundreds of kilometers south of Crozet (Park et al. 1993). The analysis of accumulated lower beaks allows us to identify 4 other onychoteuthid squids, including the poorly known Onychoteuthis sp. C and Moroteuthis sp. B (Table 2). These rare, but distinctive beaks were initially described from dietary samples of wandering albatross which bred at different localities (Imber 1992); they were recently found in the diet of royal albatrosses in the New Zealand area (Imber 1999), suggesting that both species have a circumpolar distribution in the Southern Ocean.

Taken together, king penguins and wandering albatrosses feed on a large size range of onychoteuthids, from small juveniles to adult squids. We recently hypothesized that the occurrence of small, nearly intact, specimens in the diet of king penguins indicates that spawning grounds of several cephalopods are located near the Crozet Islands (Cherel et al. 1996). The analysis of food samples from wandering albatrosses confirmed this hypothesis for 2 species, Kondakovia longimana and Moroteuthis ingens. Accumulated items in albatross stomach contents included numerous cephalopod spermatophores together with fully keratinized onychoteuthid beaks; importantly. fresh remains also included spermatophores, and sometimes intact penises containing spermatophores, which were associated with buccal masses of onychoteuthids (unpubl. data). During their foraging trips, wandering albatrosses concentrate on the southeastern edge of the Crozet shelf (Weimerskirch et al. 1994, 
1997). This suggests that the area is an important mating/spawning ground for $K$. longimana and $M$. ingens. To our knowledge, this is one of the first cephalopod reproductive areas located in the Southern Ocean.

It is surprising that onychoteuthids are common prey of albatrosses feeding at the sea-surface because they are generally considered as mesopelagic and even benthic organisms (Lubimova 1985, Nesis 1987). Recent studies show that large juveniles and immature Moroteuthis ingens live on the bottom on shelves and suggest a downward migration for spawning in deeper water (Jackson 1993, 1997, Jackson et al. 1998a), with a few spent specimens being found at depths $>700 \mathrm{~m}$ (Lipinski \& Linkowski 1986, Jackson 1997). Our data are consistent with the occurrence of juveniles in the vicinity of the Crozet Islands, where king penguins are able to catch them in the water column or even at the bottom, but they do not agree with the occurrence of adults in deep waters, where albatrosses are unable to forage. The only possible explanations for this discrepancy are, first, that mating/spawning takes place at the surface, or, second, that after copulation and spawning at deep depths, incapacitated and dying squids rise to the epipelagic. The second hypothesis is most likely to occur because onychoteuthid squids are true terminal spawners, mature and spent individuals showing advanced tissue breakdown, and some of them, including Kondakovia longimana, having been observed floating dead or dying at the sea-surface (Clarke 1980, Jackson \& Mladenov 1994, Lu \& Williams 1994, Vacchi et al. 1994. Arkhipkin \& Nigmatullin 1997, Bello 1998). Furthermore, the presence of a large amount of ammonia in the tissues of $K$. longimana, $M$. ingens and $M$. $r o b$ soni implies that onychoteuthids would normally float when dead (Lu \& Williams 1994). Rising to the surface after spawning is a common feature in other squid families such as cranchiids (including Galiteuthis glacialis) and histioteuthids (Nesis et al. 1998), which are 2 other main components of the albatross diet. Taken together, these 3 families account for $88 \%$ of the squids eaten at Crozet, suggesting that the usual way for wandering albatrosses to feed on squid is to scavenge spent individuals at the surface.

The size of onychoteuthid beaks found in wandering albatross samples at Crozet agrees well with that of beaks collected at other localities (Cooper et al. 1992, Imber 1992) and from stomachs of another adult onychoteuthid eater, the sperm whale (Clarke 1980). Our data indicate that the austral winter is a reproductive season for onychoteuthids in Crozet waters. Indeed, winter spawning was suggested from the analysis of sperm whale diet for Kondakovia longimana (Clarke 1980), and a winter peak in spawning was established from statolith increment analysis for Moroteuthis ingens (Jackson 1997). Comparison of the size of juvenile $M$. ingens eaten by wandering albatrosses with that of juveniles eaten by king penguins during the same year (1992) shows no statistical difference (Mann-Whitney $U$-test, $U=177, \mathrm{p}=0.082$ ); the 2 seabird species also preyed upon adults of the same size $(U=707.5, p=0.986)$. This indicates that only 2 size classes, one of large juveniles and one of adult individuals, co-occur in Crozet waters during the winter months. Such a bimodal distribution was consistently found at the Falkland Islands over the year. Since $M$. ingens appears to be an annual species (Jackson 1997), this suggests a main spawning peak in winter and a smaller peak in summer at the Falklands (Jackson et al. 1998a). Consequently, king penguins and wandering albatrosses probably feed on 2 different sub-populations of $M$. ingens at Crozet; albatrosses on winter reproducers and penguins on squids which reproduce later in the year.

Interannual variation was found in the size of Moroteuthis ingens (but not of Kondakovia longimana) eaten by seabirds at the Crozet Islands. Especially noticeable was the smaller ML of juvenile $M$. ingens in the diet of king penguins in winter 1991 (198 vs 230 to $235 \mathrm{~mm}$ in 1991 and 1990-92, respectively). Such a large difference in size suggests a low rate of growth due to poor food availability. In the southwestern Indian Ocean, winter 1991 was marked by an abnormal event of warm sea-surface temperature which was correlated with low body condition and poor breeding performance in some Procellariiform seabirds at Kerguelen Archipelago (Guinet et al. 1998, unpubl. data). Results on squid suggest that the marine trophic web was also influenced by this anomaly further west, at the Crozet Islands, and that fast-growing organisms, such as cephalopods, are particularly sensitive to environmental changes, which makes them potentially suitable to detect such events.

\section{Onychoteuthid squids in the Southern Ocean trophic web}

At the Crozet islands, onychoteuthid squids are eaten by various seabird species, but they are important prey items only for king penguins and wandering albatrosses in winter, and light-mantled sooty albatrosses and grey-headed albatrosses in summer (Ridoux 1994, present study). A review of the available literature to assess predation on onychoteuthids by seabirds and marine mammals revealed that many predators from various sectors of the Southern Ocean prey upon Kondakovia longimana, Moroteuthis ingens and M. knipovitchi (Table 5). Large flying seabirds mainly feed on adult squids, and also on juvenile $K$. longimana, which are known to occur in the epipelagic. 


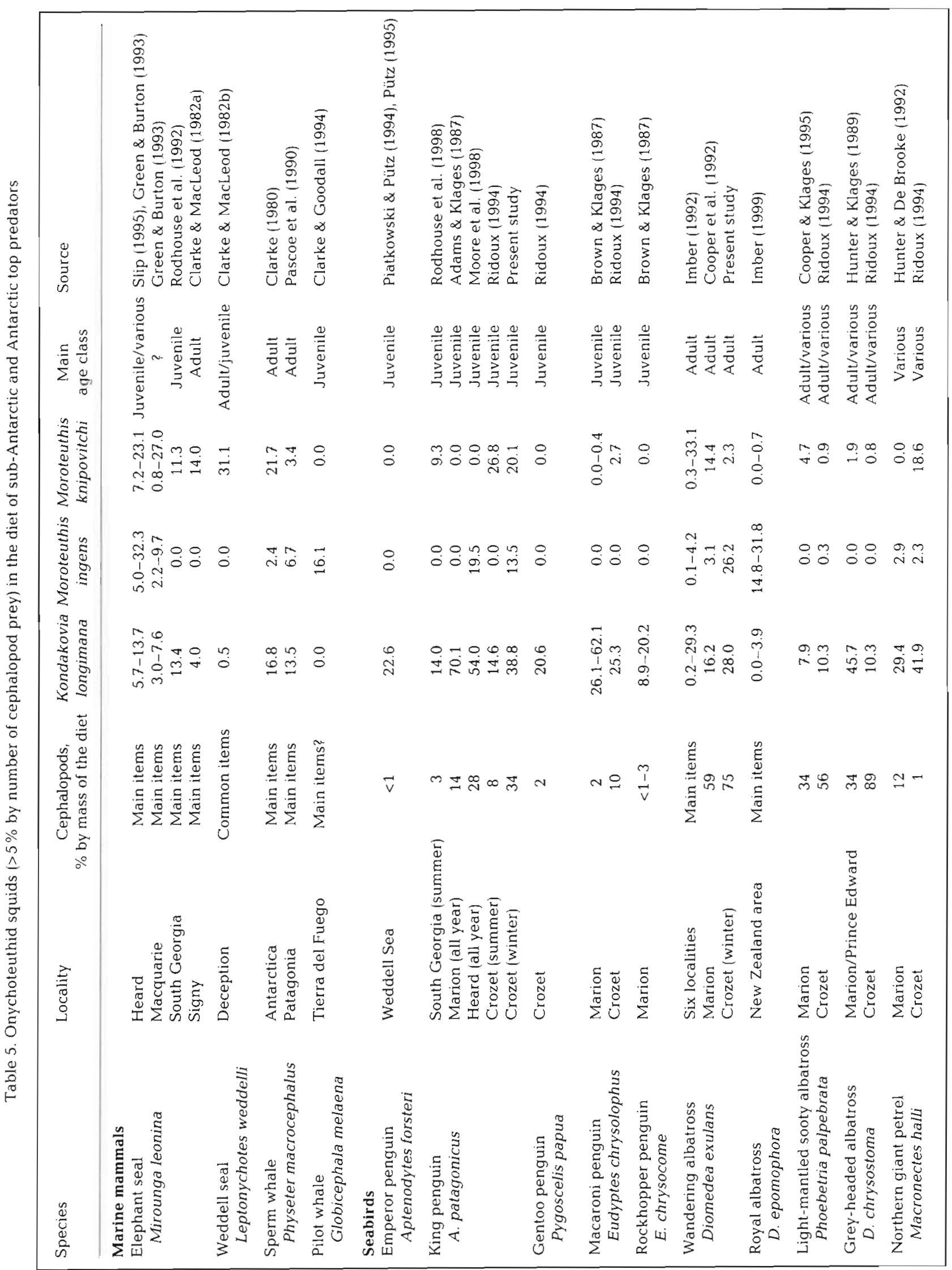


Depending on their size, diving, air-breathing vertebrates prey either upon juveniles (penguins), or on both juveniles and adults (seals), the main predator which feeds on adult cephalopods being the deepdiving sperm whale. Onychoteuthids are also eaten by some large fish and squid (see review in Jackson et al. 1998a for $M$. ingens). For example, they account for $24 \%$ of the number of cephalopods eaten by Patagonian toothfish Dissostichus eleginoides in Crozet waters (Cherel \& Duhamel unpubl. data), and $M$. ingens is an important food source for southern opah Lampris immaculatus at the Falklands (Jackson et aI. 1998a).

Little is known on the dietary habits of onychoteuthid squids, but a recent study shows that Moroteuthis ingens feeds on mesopelagic fish and squid, including conspecifics (Jackson et al. 1998b). Onychoteuthids appear to prey upon Antarctic krill Euphausia superba at higher latitudes, and upon myctophid fish and squid further north (Lubimova 1985, Nemoto et al. 1988). At Crozet, it is more likely that they depend on myctophids because no Antarctic krill occurs in the area, and juvenile $M$. ingens have always been associated with myctophids in king penguin stomach contents (Cherel et al. 1996). As noted in New Zealand waters (Jackson et al. 1998b), onychoteuthids thus belong to a previously unrecognised food chain in the Southern Ocean linking zooplankton, mesopelagic fish, squid and higher predators, including seabirds and marine mammals. In the southwestern Indian Ocean, the role of onychoteuthids in the trophic web is further emphasized by their importance in the diet of sperm whales (Mikhalev et al. 1981), possibly beaked whales (Slip et al, 1995), and seabirds and marine mammals (Guinet et al. 1996, present study).

Acknowledgements. The authors thank C. Verdon, E. Challet and J. Durant for collecting king penguin samples, and $F$. Cuénot-Chaillet and P. Lys for collecting wandering albatross samples at Possession Island. We are very grateful for the help and advice of M. Imber, N. Klages, V. Ridoux and P. Rodhouse in identifying cephalopod beaks. Analysis of king penguin food was performed at the Centre d'Ecologie et Physiologie Energétiques, Strasbourg, France. This work was supported financially and logistically by the Institut Français pour la Recherche et la Technologie Polaires and the Terres Australes et Antarctiques Françaises.

\section{LITERATURE CITED}

Adams NJ, Klages NT (1987) Seasonal variation in the diet of the king penguin (Aptenodytes patagonicus) at subAntarctic Marion Island. J Zool Lond 212:303-324

Arkhipkin AI, Nigmatullin CM (1997) Ecology of the oceanic squid Onychoteuthis banksi and the relationship between the genera Onychoteuthis and Chaunoteuthis (Cephalopoda: Oriychoteuthidae). J Mar Biol Assoc UK 77:839-869
Bello G (1998) Chaunoteuthis mollis: re-examination of a Mediterranean specimen and its identity with Onychoteuthis banksii (Cephalopoda: Onychoteuthidae). J Mar Biol Assoc UK 78:1027-1030

Bost CA, Georges JY, Guinet C, Cherel Y, Pütz K, Charrassin JB, Handrich Y, Zorn T, Lage J, Le Maho Y (1997) Foraging habitat and food intake of satellite-tracked king penguins during the austral summer at Crozet Archipelago. Mar Ecol Prog Ser 150:21-33

Brown CR, Klages NT (1987) Seasonal and annual variation in diets of macaroni (Eudyptes chrysolophus chrysolophus) and southern rockhopper (E. chrysocome chrysocome) penguins at sub-Antarctic Marion Island. J Zool Lond 212: $7-28$

Cherel Y, Klages N (1998) A review of the food of albatrosses. In: Robertson $G$, Gales $R$ (eds) Albatross biology and conservation. Surrey Beatty and Sons, Chipping Norton, p $113-136$

Cherel Y, Weimerskirch $H$ (1995) Seabirds as indicators of marine resources: black-browed albatrosses feeding on ommastrephid squids in Kerguelen waters. Mar Ecol Prog Ser 129:295-300

Cherel Y, Stahl JC, Le Maho Y (1987) Ecology and physiology of fasting in king penguin chicks. Auk 104:254-262

Cherel Y, Charrassin JB, Handrich Y (1993a) Comparison of body reserve buildup in prefasting chicks and adults of king penguins (Aptenodytes patagonicus). Physiol Zool $66: 750-770$

Cherel Y, Verdon C, Ridoux V (1993b) Seasonal importance of oceanic myctophids in king penguin diet at Crozet Islands. Polar Biol 13:355-357

Cherel Y, Ridoux V, Rodhouse PG (1996) Fish and squid in the diet of king penguin chicks, Aptenodytes patagonicus, during winter at sub-antarctic Crozet Islands. Mar Biol 126:559-570

Clarke MR (1980) Cephalopoda in the diet of sperm whales of the Southern Hemisphere and their bearing on sperm whale biology. Discovery Rep 37:1-324

Clarke MR (1986) A handbook for the identification of cephalopod beaks. Clarendon Press, Oxford

Clarke MR, Goodall N (1994) Cephalopods in the diets of three odontocete cetacean species stranded at Tierra del Fuego, Globicephala melaena (Traill, 1809), Hyperoodon planifrons Flower, 1882 and Cephalorhynchus conmersonii (Lacepede, 1804). Antarct Sci 6:149-154

Clarke MR, MacLeod N (1982a) Cephalopods in the diet of elephant seals at Signy Island, South Orkney Islands. Br Antarct Surv Bull 57:27-31

Clarke MR, MacLeod N (1982b) Cephalopod remains in the stomachs of eight Weddell seals. Br Antarct Surv Bull 57: $33-40$

Cooper J, Klages NTW (1995) The diets and dietary segregation of sooty albatrosses (Phoebetria spp.) at subantarctic Marion Island. Antarct Sci 7:15-23

Cooper J, Henley SR, Klages NTW (1992) The diet of the wandering albatross Diomedea exulans at sub-antarctic Marion Island. Polar Biol 12:477-484

Croxall JP (1984) Seabirds. In: Laws RM (ed) Antarctic ecology, Vol 2. Academic Press, London, p 533-619

Croxall JP, Prince PA (1994) Dead or alive, night or day: how do albatrosses catch squid? Antarct Sci 6:155-162

Furness BL, Laugksch RC, Duffy DC (1984) Cephalopod beaks and studies of seabird diets. Auk 101:619-620

Gales RP (1987) Validation of the stomach-flushing technique for obtaining stomach contents of penguins. Ibis 129: $335-343$

Green K, Burton HR (1993) Comparison of the stomach con- 
tents of southern elephant seals, Mirounga leonina, at Macquarie and Heard Islands. Mar Mamm Sci 9:10-22

Guinet C, Jouventin P, Malacamp $J$ (1995) Satellite remote sensing in monitoring change of seabirds: use of Spot Image in king penguin population increase at lle aux Cochons, Crozet Archipelago. Polar Biol 15:511-515

Guinet C, Cherel Y, Ridoux V, Jouventin P (1996) Consumption of marine resources by seabirds and seals in Crozet and Kerguelen waters: changes in relation to consumer biomass 1962-85. Antarct Sci 8:23-30

Guinet C, Chastel O, Koudil M, Durbec JP, Jouventin P (1998) Effects of warm sea-surface temperature anomalies on the blue petrel at the Kerguelen Islands. Proc R Soc Lond B 265:1001-1006

Hindell MA (1988) The diet of the king penguin Aptenodytes patagonicus at Macquarie Island. Ibis 130:193-203

Hunter S, De Brooke M (1992) The diet of giant petrels Macronectes spp. at Marion Island, southern Indian Ocean. Colon Waterbirds 15:56-65

Hunter S, Klages NTW (1989) The diet of grey-headed albatrosses Diomedea chrysostoma at the Prince Edward Islands. S Afr J Antarct Res 19:31-33

Imber MJ (1992) Cephalopods eaten by wandering albatrosses (Diomedea exulans L.) breeding at six circumpolar localities. J R Soc NZ 22:243-263

Imber MJ (1999) Diet and feeding ecology of the royal albatross Diomedea epomophora. King of the shelf break and inner slope. Emu 99:200-211

Jackson GD (1993) Growth zones within the statolith microstructure of the deepwater squid Moroteuthis ingens (Cephalopoda: Onychoteuthidae): evidence for a habitat shift? Can J Fish Aquat Sci 50:2366-2374

Jackson GD (1995) The use of beaks as tools for biomass estimation in the deepwater squid Moroteuthis ingens (Cephalopoda: Onychoteuthidae) in New Zealand waters. Polar Biol 15:9-14

Jackson GD (1997) Age, growth and maturation of the deepwater squid Moroteuthis ingens (Cephalopoda: Onychoteuthidae) in New Zealand waters. Polar Biol 17:268-274

Jackson GD, Mladenov PV (1994) Terminal spawning in the deepwater squid Moroteuthis ingens (Cephalopoda: Onychoteuthidae). J Zool Lond 234:189-201

Jackson GD, George MJA, Buxton NG (1998a) Distribution and abundance of the squid Moroteuthis ingens (Cephalopoda: Onychoteuthidae) in the Falkland Is]ands region of the South Atlantic. Polar Biol 20:161-169

Jackson GD, McKinnon JF, Lalas C, Ardern R, Buxton NG (1998b) Food spectrum of the deep water squid Moroteuthis ingens (Cephalopoda: Onychoteuthidae) in New Zealand waters. Polar Biol 20:56-65

Jouventin $P$, Capdeville $D$, Cuénot-Chaillet $F$, Boiteau C (1994) Exploitation of pelagic resources by a non-flying seabird: satellite tracking of the king penguin throughout the breeding cycle. Mar Ecol Prog Ser 106:11-19

Kock KH (1987) Marine consumers: fish and squid. Environ Int 13:37-45

Kooyman GL, Cherel Y, Le Maho Y, Croxall JP, Thorson PH, Ridoux V, Kooyman CA (1992) Diving behavior and energetics during foraging cycles in king penguins. Ecol Monogr 62:143-163

Kubodera T, Piatkowski U, Okutani T, Clarke MR (1998) Taxonomy and zoogeography of the family Onychoteuthidae (Cephalopoda; Oegopsida). Smithson Contrib Zool 586: $277-291$

Lequette $B$, Weimerskirch $H$ (1990) Influence of parental experience on the growth of wandering albatrosses. Condor $92: 726-731$
Lipinski MR, Linkowski TB (1986) Some aspects of the biology of squid Moroteuthis ingens (Onychoteuthidae) from New Zealand waters. Rep Sea Fish Inst 21:97-105

Lu CC. Williams R (1994) Kondakovia longimana Filippova, 1972 (Cephalopoda: Onychoteuthidae) from the Indian Ocean sector of the Southern Ocean. Antarct Sci 6 231-234

Lubimova TG (1985) Results of soviet investigations of the distribution and ecology of pelagic squids (Oegopsida) in the Southern Ocean. Select Scient Papers CCAMLR 1985 $79-111$

Mikhalev JA, Savusin VP, Kishiyan NA (1981) To the problem of the feeding of sperm whales from the Southern Hemisphere. Rep Int Whal Comm 31:737-745

Moore GJ, Robertson G. Wienecke B (1998) Food requirements of breeding king penguins at Heard Island and potential overlap with commercial fisheries. Polar Biol 20: $293-302$

Nemoto T, Okiyama M, Iwasaki N, Kikuchi T (1988) Squid as predators on krill (Euphausia superba) and prey for sperm whales in the Southern Ocean. In: Sahrhage D (ed) Antarctic Ocean and resource variability. Springer-Verlag, Berlin, p 292-296

Nesis KN (1987) Cephalopods of the world. Squids, cuttlefishes, octopuses and allies. TFH Publications, Neptune City, NJ

Nesis KN, Nigmatullin CM, Nikitina IV (1998) Spent females of deepwater squid Gafiteuthis glacialis under the ice at the surface of the Weddell Sea (Antarctic). J Zool Lond 244:185-200

Park YH, Gambéroni L, Charriaud E (1993) Frontal structure, water masses, and circulation in the Crozet Basin. J Geophys Res 98:12361-12385

Pascoe PL, Mickiewicz MC, Castello HP (1990) Cephalopod remains from the stomach of a sperm whale stranded off Patagonia. Mar Biol 104:1-4

Piatkowski U, Pütz K (1994) Squid diet of emperor penguins (Aptenodytes forster) in the eastern Weddell Sea, Antarctica during late summer. Antarct Sci 6:241-247

Prince PA, Huin N, Weimerskirch H (1994) Diving depths of albatrosses. Antarct Sci 6:353-354

Pütz K (1995) The post-moult diet of emperor penguins (Aptenodytes forsterl) in the eastern Weddell Sea, Antarctica. Polar Biol 15:457-463

Pütz K, Wilson RP, Charrassin JB, Raclot T, Lage J, Le Maho $Y$, Kierspel MAM, Culik BM, Adelung D (1998) Foraging strategy of king penguins (Aptenodytes patagonicus) during summer at the Crozet Islands. Ecology 79:1905-1921

Ridoux (1994) The diets and dietary segregation of seabirds at the subantarctic Crozet Islands. Mar Ornithol 22:1-92

Rodhouse PG (1990) Cephalopod fauna of the Scotia Sea at South Georgia: potential for commercial exploitation and possible consequences. In: Kerry KR, Hempel G (eds) Antarctic ecosystems. Ecological change and conservation. Springer-Verlag, Berlin, p 289-298

Rodhouse PG, Clarke MR, Murray AWA (1987) Cephalopod prey of the wandering albatross Diomedea exulans. Mar Biol 96:1-10

Rodhouse PG, Arnbom TR, Fedak MA, Yeatman J, Murray AWA (1992) Cephalopod prey of the southern elephant seal, Mirounga leonina L. Can J Zool 70:1007-1015

Rodhouse PG, Prince PA, Trathan PN, Hatfield EMC, Watkins JL, Bone DG, Murphy EJ, White MG (1996) Cephalopods and mesoscale oceanography at the Antarctic Polar Front: satellite tracked predators locate pelagic trophic interactions. Mar Ecol Prog Ser 136:37-50

Rodhouse $\mathrm{PG}$, Olsson $\mathrm{O}$, Anker-Nilssen $\mathrm{P}$, Murray AWA 
(1998) Cephalopod predation by the king penguin Aptenodytes patagonicus from South Georgia. Mar Ecol Prog Ser 168:13-19

Slip DJ (1995) The diet of southern elephant seals (Mirounga leonina) from Heard Island. Can J Zool 73:1519-1528

Slip DJ, Moore GJ, Green K (1995) Stomach contents of a southern bottlenose whale, Hyperoodon planifrons, stranded at Heard Island. Mar Mamm Sci 11:575-584

Smith SL, Schnack-Schiel SB (1990) Polar zooplankton. In: Smith WO (ed) Polar oceanography, Part B. Academic Press, San Diego, p 527-598

Tickell WLN (1968) The biology of the great albatrosses, Diomedea exulans and Diomedea epomophora. Antarct Res Ser 12:1-55

Vacchi M, Greco S, La Mesa M (1994) Kondakovia longimana Filippova, 1972 (Onychoteuthidae) from Terra Nova Bay, Ross Sea. Antarct Sci 6:283

Weimerskirch H, Jouventin P (1987) Population dynamics of

Editorial responsibility: Otto Kinne (Editor),

Oldendorf/Luhe, Germany the wandering albatross, Diomedea exulans, of the Crozet Islands: causes and consequences of the population decline. Oikos 49:315-322

Weimerskirch H, Jouventin P, Stahl JC (1986) Comparatjve ecology of the six albatross species breeding on the Crozet Islands. Ibis 128:195-213

Weimerskirch H, Doncaster CP, Cuénot-Chaillet F (1994) Pelagic seabirds and the marine environment: foraging patterns of wandering albatrosses in relation to prey availability and distribution. Proc R Soc Lond B 255:91-97

Weimerskirch $\mathrm{H}$, Cherel $\mathrm{Y}$, Cuénot-Chaillet $\mathrm{F}$, Ridoux V (1997) Alternative foraging strategies and resource allocation by male and female wandering albatrosses. Ecology 78:2051-2063

Xavier JC, Rodhouse PG, Trathan PN, Wood AG (1999) A geographical information system (GIS) atlas of cephalopod distribution in the Southern Ocean. Antarct Sci 11: $61-62$

Submitted: February 1, 1999; Accepted: April 9, 1999 Proofs received from author(s): October 11, 1999 